\title{
Ultrasonographie transrectale dans la maladie de Crohn
}

\author{
M.H. De MAEYER, M.J. VAN OUTRYVE, P.A. PELCKMANS, Y. VAN MAERCKE \\ Antwerp University Hospital (Belgium)
}

\section{Transrectal ultrasonography in Crohn's disease}

\section{RÉSUMÉ}

En gastro-entérologie, l'ultrasonographie transrectale est un examen de premier choix dans la stadification des tumeurs anorectales. Dans la maladie de Crohn, l'ultrasonographie transrectale a mis en évidence des abcès et des fistules méconnus par les examens proctologiques. En outre, l'examen sonographique a détecté des anomalies de la paroi rectale et du sphincter anal. Ces anomalies peuvent précéder les lésions muqueuses (superficielles) et persister pendant la phase de guérison. La détection précoce des lésions anorectales dans la maladie de Crohn devrait faciliter un traitement rapide et adéquat.

\section{SUMMARY}

In gastroenterology, transrectal ultrasonography is widely applied in the staging of anorectal tumors. In Crohn's disease, transrectal ultrasonography revealed abscesses and fistulas, missed by the other proctological examinations. The technique also detected anomalies of the rectal wall and of the anal sphincter structure. These anomalies can precede the mucosal lesions and often persist in the healing phase. The early sonographic detection of anorectal lesions in Crohn's disease should facilitate an early and adequate treatment.

\section{INTRODUCTION}

L'ultrasonographie transrectale (UST) a été jusqu'à présent largement utilisée dans la stadification des tumeurs anorectales [1, 4]. Sa valeur dans la maladie de Crohn a été l'objet d'une évaluation récente $[7,8]$. Cette technique facile à réaliser, est très sensible en pathologie anorectale. Dans la maladie de Crohn, l'UST est le complément de la procto-sigmoïdoscopie et elle détecte des lésions qui ont été méconnues par l'endoscopie et la tomodensitométrie computée.

L'emploi d'une sonde endorectale Toshiba (IUV 5060 ; fréquence moyenne $5 \mathrm{MHz}$ ), avec fenêtre ultrasonique linéaire et radiale, permet au cours du même examen une exploration linéaire et radiale de la région anorectale. Selon nous, l'approche linéaire fournit les meilleures conditions d'observation, spécialement au niveau du sphincter anal $[5,8]$. Les images illustrant le présent article ont été réalisées en approche linéaire.

L'UST visualise la paroi rectale, le sphincter anal, la vessie et le plancher musculaire pelvien. Au niveau pelvis, chez l'homme, l'examen permet l'exploration de la prostate et des vésicules séminales et chez la femme, du col utérin et du vagin.

\section{RÉSULTATS ET DISCUSSION}

\section{Paroi rectale}

La totalité de la paroi rectale comporte 5 couches : deux hypoéchogènes, et trois hyperéchogènes $[1,2]$. La muqueuse apparaît sous forme d'une zone hypo-échogène au contact du ballon et le muscle propre se présente comme la zone hypo-échogène la plus externe (Figure 1).

Les trois couches hyper-échogènes représentent les interfaces, et sont le résultat des différences d'impédance ultrasonique.

L'épaisseur maximale de la paroi rectale est de $4 \mathrm{~mm}$, lorsqu'elle est mesurée entre le sommet de la première couche interface jusqu'au fond de la troisième $[3,6]$. Les dimensions de la paroi rectale et des couches séparées peuvent être évaluées avec précision uniquement par UST, contrairement à la tomodensitométrie et les autres techniques d'imagerie.

Un élargissement pathologique de la paroi rectale au-dessus de $4 \mathrm{~mm}$ a été observé chez $40 \%$ des patients atteints de maladie de Crohn (Figure 2). Cet élargissement n'est jamais observé chez les sujets normaux [8].

Tirés à part: M.J. VAN OUTRYVE, Div. of Gastroenterology, University Hospital of Antwerp, UIA, Edegem (Belgium).

Mots-clés : maladie de Crohn, sphincter anal, ultrasonographie transrectale.

Key-words : anal sphincter, Crohn's disease, transrectal ultrasonography. 


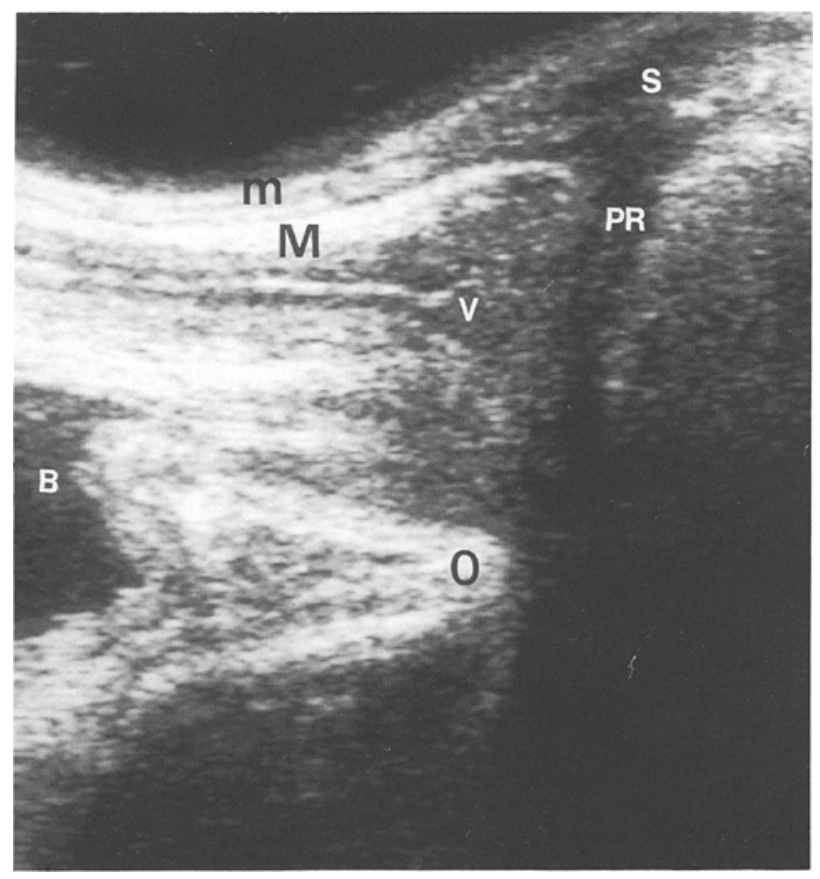

Figure 1

Paroi rectale normale chez un sujet sain. Remarquez les deux couches pauvres en échos : la muqueuse $(\boldsymbol{m})$ et le muscle propre (W). Images distinctes de la vessie (b), du vagin (v), de l'os pubique (o), du $\mathrm{m}$. puborectal (pr) et du sphincter anal (s).

Normal rectal wall structure in healthy subject. Remark the two echopoor layers: the mucosa $(\boldsymbol{m})$ and the muscularis propria (M). Clear imaging of the urinary bladder (b), the vagina (v), the os pubis (o), of the $\mathrm{m}$. puborectalis (pr) and the anal sphincter (s).

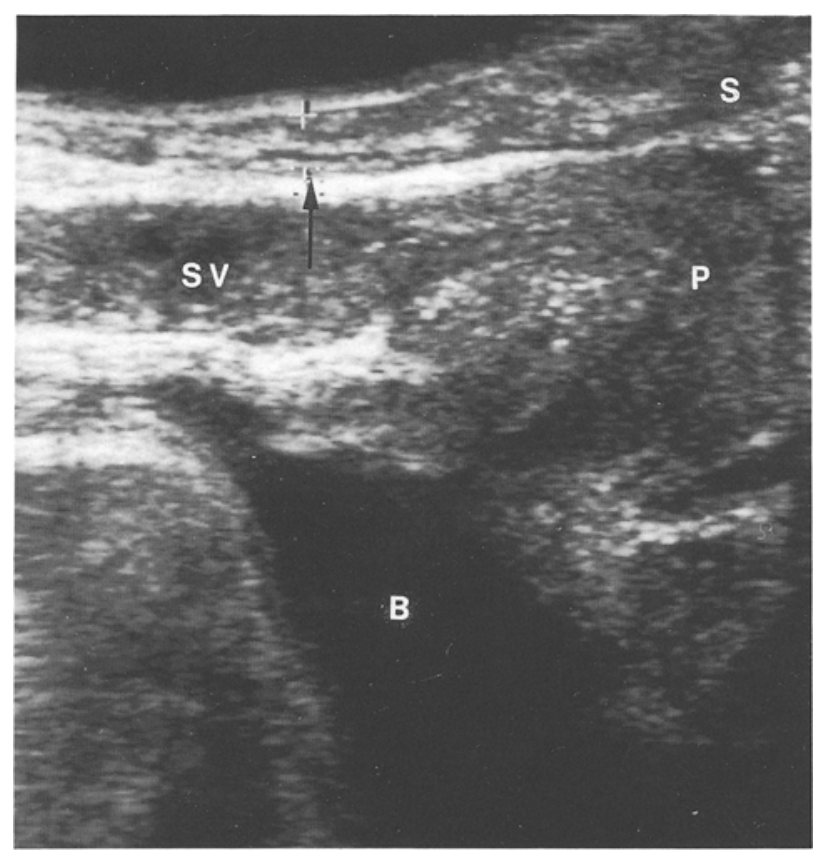

Figure 2

Paroi rectale anormale et légèrement élargie (flèche) chez un homme de 31 ans souffrant de maladie de Crohn de longue durée. Le sphincter anal (s) est hétérogène, avec alternances de zones pauvres et de zones riches en échos. Notez la vésicule séminale (sv), la prostate (p) et la vessie (b).

Abnormal rectal wall, with strikingly increased thickness (arrow) in a 31 yrs old man with longstanding Crohn's disease. The anal sphincter (s) is heterogeneous, with alternating echopoor and echorich areas. Notice the seminal vesicle (sv), the prostate (p) and the urinary bladder (b).
Les malades porteurs de lésions actives anorectales de maladie de Crohn ont plus fréquemment un élargissement pathologique de la paroi rectale que les patients qui n'ont jamais présenté d'aspect endoscopique évocateur d'une localisation anorectale.

La signification exacte de l'élargissement de la paroi rectale dans la maladie de Crohn n'a jusqu'à présent pas donné lieu à des études de surveillance. Elle correspondrait à une inflammation transmurale, qui précède les lésions muqueuses, et persiste fréquemment après guérison de ces lésions.

\section{Sphincter anal}

En UST, le sphincter anal se présente normalement comme une zone limitée, ellipsoïde et hypo-échogène dans sa partie interne, prenant son départ dans la couche musculaire rectale (Figure 3). La longueur et la largeur du sphincter peuvent être aisément mesurées au stade de repos et en phase de rétention et de poussée. La rétention est la contraction volontaire du sphincter anal destinée à retenir le contenu rectal. La poussée est le mouvement volontaire effectué en vue de déféquer et d'éliminer le contenu intra-luminal. En cours de rétention, le sphincter se raccourcit et s'élargit. Le contraire survient en cas de poussée, en vue d'ouvrir le canal anal.

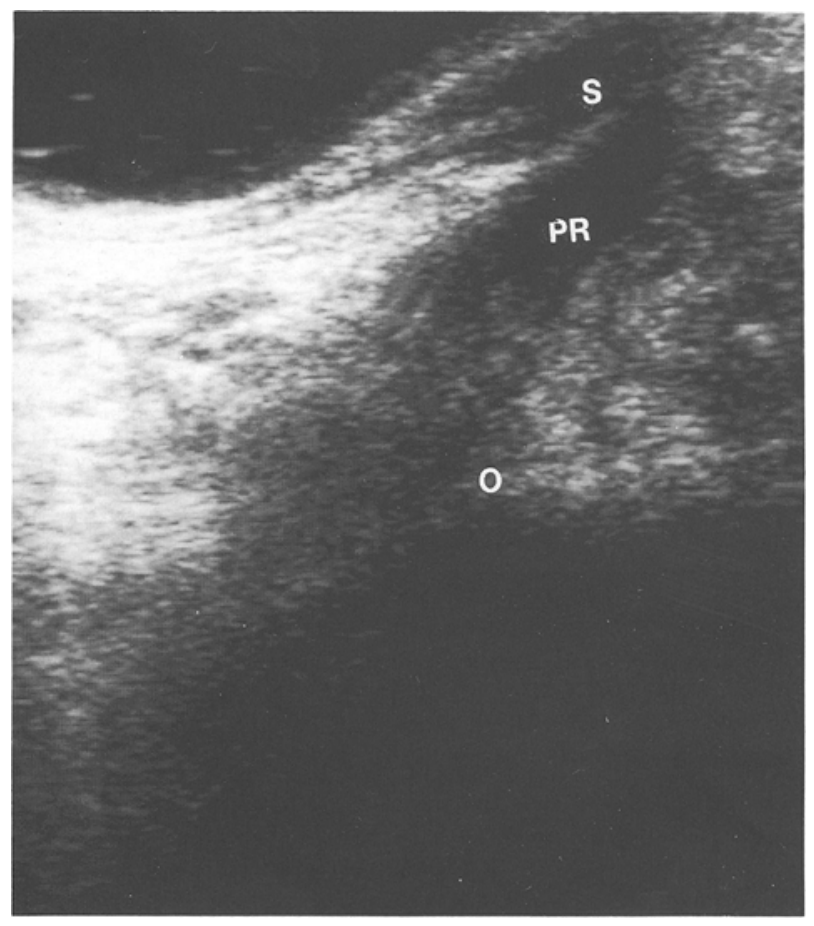

Figure 3

Sphincter anal (s) normal à structure homogène, chez un sujet sain. Remarquez le m. puborectal (pr), reliant l'os pubique (o), à la partie externe du sphincter anal.

Normal anal sphincter (s) with typical homogeneous echopoor structure, in a healthy subject. Notice the $\mathrm{m}$. puborectalis (pr), originating from the os pubis (o) and joining the external part of the anal sphincter. 


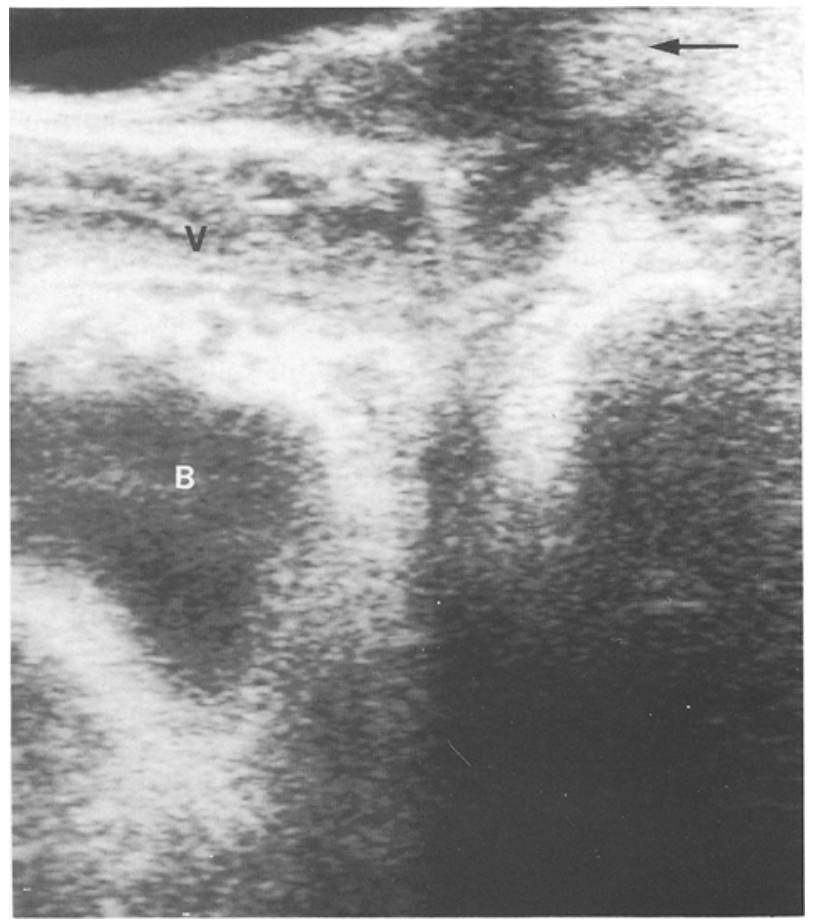

Figure 4

Sphincter anal inhomogène chez une femme de 19 ans, présentant une maladie de Crohn anorectale active. La partie distale du sphincter est nettement plus riche en échos (tideche) que la partie proximale. Remarquez le vagin $(\boldsymbol{v})$ et la vessie (b).

Inhomogeneous anal sphincter with echorich area distally (arrow) in a

19 yrs old girl with active anorectal Crohn's disease. Notice the vagina ( $v$ ) and the urinary bladder (b).

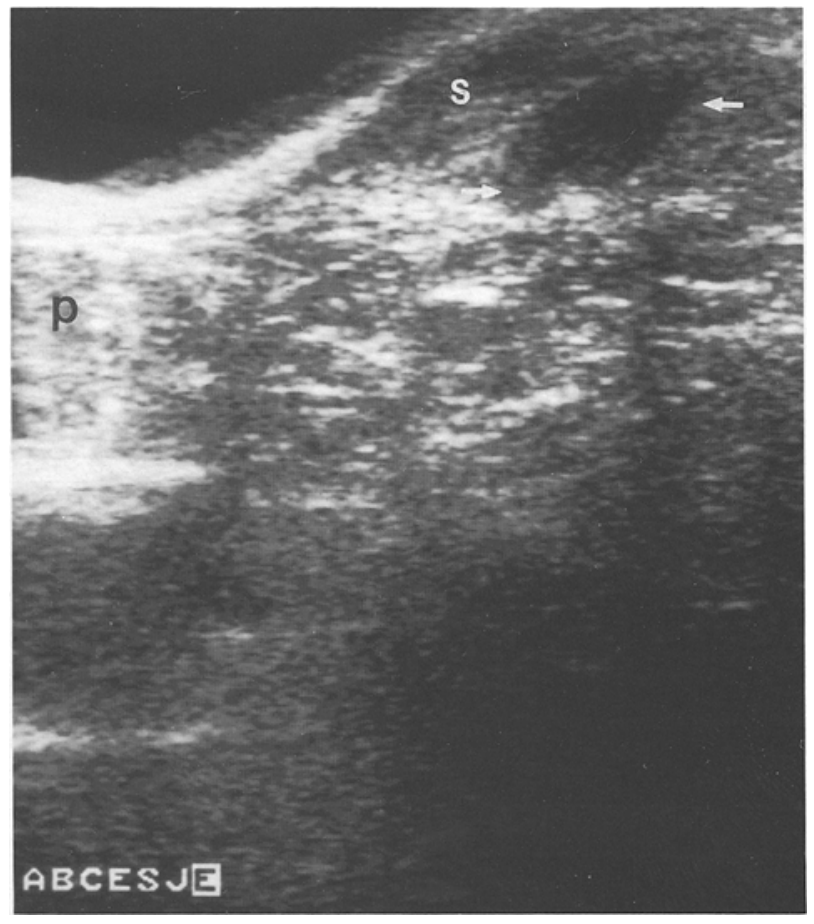

Figure 5

Abcès para-anal (fỉches) à caractère transparent et renforcement postérieur chez un homme de 39 ans souffrant de maladie de Crohn active. Remarquez la prostate (p) et le sphincter anal (s)

Para-anal abscess (arrows), with typical echopoor structure and posterior echo enhancement in a $39 \mathrm{yrs}$ old man with active Crohn's disease. Notice the prostate (p) an the anal sphincter (s)
Chez le sujet sain, le sphincter est une zone relativement homogène [8]. Par contre, chez la moitié des patients souffrant de maladie de Crohn, une échostructure diffusément inhomogène a été observée au niveau de la zone sphinctérienne (Figure 4). Ces anomalies s'observent plus particulièrement chez les patients porteurs d'une lésion de maladie de Crohn active, localisée à la région anorectale, et elles persistent après guérison des lésions proctologiques. Ceci est probablement la conséquence d'inflammation chronique dans le sphincter anal, avec pour résultat final, des zones de fibrose irréversible.

\section{Abcès et fistules}

Les abcès et fistules se caractérisent par des images spécifiques en UST. Un abcès s'exprime par une masse hypo-échogène bien délimitée avec renforcement postérieur [9]. Chez nos patients, les abcès avaient une localisation para-rectale ou paraanale (Figure 5).

Une fistule est caractérisée par une colonne pointillée de bulles d'air hyper-échogènes avec réverbérations [2].

La Figure 6 présente une illustration d'une fistule para-anale.

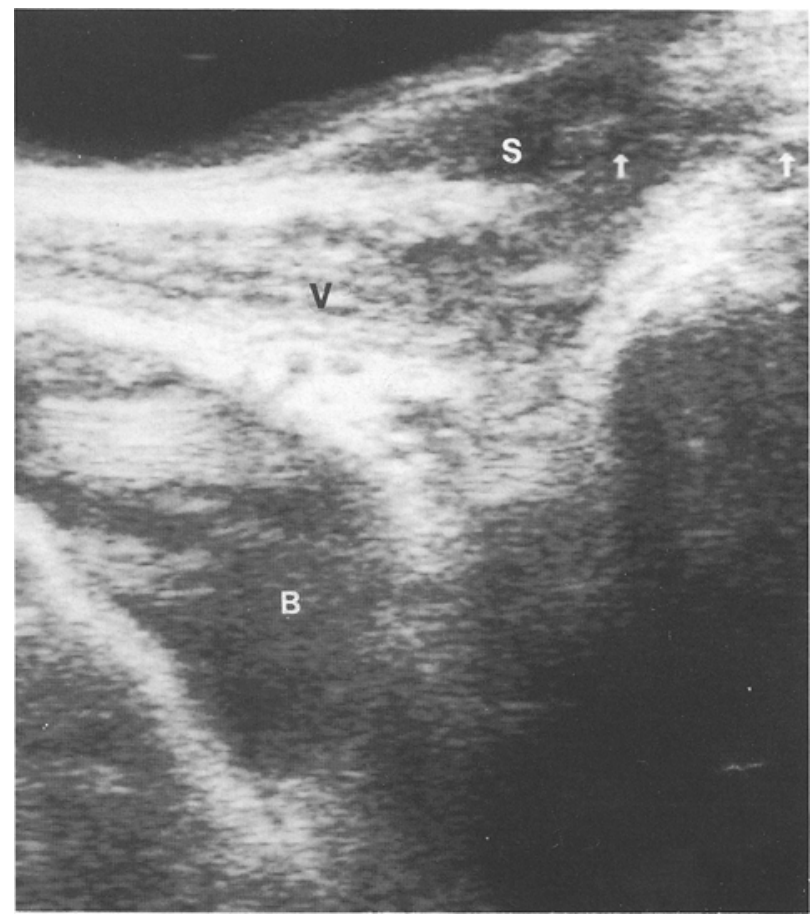

Figure 6

Même malade qu'à la Figure 4. On remarque la petite fistule (fleches) prenant origine dans la partie ventrale du sphincter anal (s) et dirigée vers l'orifice extérieur. Notez le vagin (v) et la vessie (b).

Same patient as in Figure 4, with a small fistula (arrows) originating ventrally in the anal sphincter (s) and running distally towards the perianal skin. Notice the vagina (v) and the urinary bladder (b). 
Chez plusieurs patients atteints de maladie de Crohn, l'UST identifie des abcès et fistules, méconnus par d'autres méthodes d'examen endoscopique et radiologique. En outre, toutes les fistules et abcès précédemment mis en évidence par examen proctologique ont été clairement définis par UST et ont été suivis par méthode ultrasonographique en cours de traitement.

\section{CONCLUSIONS}

L'ultrasonographie transrectale (UST) est une technique commode et fiable, bien tolérée par le patient.

Différents paramètres peuvent être évalués avec exactitude par UST : structure et épaisseur de la paroi rectale, morphologie et dimensions du sphincter anal, et évaluation de la musculature du plancher pelvien. Dans le cas particulier de l'évaluation de la morphologie et de la fonction dynamique du sphincter anal, le scanning linéaire ultrasonique semble plus pratique que l'approche radiale.

Dans la maladie de Crohn, l'UST révèle des lésions qui n'avaient pas été identifiées par la proctosigmoïdoscopie de routine, et donne une excellente représentation tri-dimensionnelle de leur relation avec les tissus voisins. La détection précoce d'anomalies du sphincter anal et de la paroi rectale permet un traitement plus rapide et plus précis.

L'UST semble une technique très prometteuse dans l'étude des maladies anorectales non néoplasiques.

\section{RÉFÉRENCES}

1. BOSCAINI M. MONTORI A. - Transrectal ultrasonogra phy : interpretation of normal intestinal wall structure for the preoperative staging of rectal cancer. Scand. J. Gastroenterol., 1986, 21 (suppl. 123), 87-98.

2. HILDEBRANDT U., FEIFEL G., ECKER K.W. - Rectal endosonography. Ballières Clin. Gastroenterol., 1989, 3, 531541.

3. LIMBERG B. - Differentialdiagnose akut entzündlicher Dickdarmerkrankungen durch Kolonsonographie. Disch. Med. Wochenschr., 1987, 112, 382-385.

4. ORROM W.J., WONG W.D., ROTHENBERGER D.A., JENSEN L.L., GOLDBERG S.M. - Endorectal utrasound in the preoperative staging of rectal tumors: a learning experience. Dis. Colon Rectum, 1990, 33, 654-660.

5. PELCKMANS P.A., VAN OUTRYVE M.J., MICHIELSEN P.P., VAN MAERCKE Y.M. - Endosonography of

\section{INTRODUCTION}

Transrectal Ultrasonography (TRU) has already been widely used in the staging of anorectal tumors $[1,4]$. Its value in Crohn's disease has recently been evaluated $[7,8]$. The technique is easy to perform and very sensitive to demonstrate anorectal pathology. TRU is complementary to proctosigmoidoscopy in Crohn's disease, since it detects lesions missed by endoscopy and by CT-scan.

Using the Toshiba endorectal probe (IUV 5060 ; mean frequency $5 \mathrm{MHz}$ ) with a linear and a radial ultrasonic window, both a linear and radial evaluation of the anorectal region can be made during the same examination. In our opinion, the linear approach gives the most surveyable images, especially of the anal sphincter $[5,8]$. The images in this text were made by linear scanning.

$T R U$ visualizes the rectal wall, the anal sphincter, the urinary bladder and the pelvic floor musculature. In the male pelvis the prostate gland and seminal vesicles can be evaluated, in the female pelvis the cervix and the vagina. the anal sphincter and anorectum (abstr.). Gastroenterology, 1988, 94, A348.

6. RASMUSSEN S.N., RIIS P. - Rectal wall thickness measured by ultrasound in chronic inflammatory diseases of the colon. Scand. J. Gastroenterol., 1985, 20, 109-114.

7. TIO T.L., MULDER C.J., WIJERS O.B., SARS P.R., TYTGAT G.N. - Endosonography of peri-anal and pericolorectal fistula and/or abscess in Crohn's disease. Gastrointest. Endosc., 1990, 36, 331-336.

8. VAN OUTRYVE M.J., PELCKMANS P.A., MICHIELSEN P.P., VAN MAERCKE Y.M. Value of transrectal ultrasonography in Crohn's disease. Gastroenterology, 1991, $101,1171-1177$

9. WEILL F.S. - Ultrasound diagnosis of digestive diseases. $3^{\text {rd }}$ ed. New York : Springer 1990.

\section{RESULTS AND DISCUSSION}

\section{Rectal wall}

The entire rectal wall consists of 5 layers : two echopoor and three echorich [1,2]. The mucosa is defined as the hypo-echoic layer nearest to the balloon and the muscularis propria as the outermost hypo-echoic layer (Figure 1).

The three echorich layers represent interfaces and are the result of differences in ultrasonic impedance.

The maximal thickness of the rectal wall is $4 \mathrm{~mm}$, when measured from the top of the first interface layer to the bottom of the third interface layer $[3,6]$. The dimensions of the rectal wall and its separate layers can be studied accurately only with TRU, not with CT-scan or other imaging techniques.

A pathological enlargement of the rectal wall of more than $4 \mathrm{~mm}$ was found in $40 \%$ of our patients with Crohn's disease (Figure 2). This enlargement was never encountered in normal subjects [8]. 
Patients with active anorectal Crohn's lesions had more frequently a pathological wall enlargement than patients which never presented any endoscopic evidence of anorectal involvement. The exact meaning of this rectal wall enlargement in Crohn's disease has yet to be evaluated in follow-up studies. It could represent transmural inflammation, which precedes mucosal lesions and often persists after healing of these lesions.

\section{Anal sphincter}

On TRU, the anal sphincter appears normally as a sharply delinated ellipsoid and echopoor area, in its internal part, originating from the rectal muscular layer (Figure 3). The sphincter length and breadth can easily be measured in resting state and during squeezing or straining. Squeezing is the voluntary anal sphincter contraction to retain intrarectal contents. Straining is the voluntary movement to defecate, to expel intraluminal contents. While squeezing, the sphincter becomes shorter and larger. The opposite happens while straining, to open the anal canal.

In healthy subjects, the sphincter is a quite homogeneous area [8]. In contrast to this, in about half of our patients with Crohn's disease a diffusely inhomogenic echostructure of the sphincter was found (Figure 4). These anomalies were especially encountered in patients with active anorectal Crohn's lesion, and persisted after healing of the proctologic lesions. Probably this is provoked by irreversible fibrotic areas in the anal sphincter, as an end result of chronic inflammation.

\section{Abcesses and fistulas}

Abcesses and fistulas show specific characteristics on TRU examination. An abcess is represented by a sharply delineated echopoor mass with posterior enhancement [9].
In our patients the abcesses were localized pararectally or para-anally (Figure 5).

A fistula is characterized by a dotty column of echorich air bubbles with reverberations [2]. tula.

Figure 6 shows an illustration of para-anal fis-

In several patients with Crohn's disease, TRU detected abcesses and fistulas, missed by the other endoscopic or radiological examinations. Moreover, all the anorectal abcesses and fistulas previously demonstrated on proctoscopy were clearly outlined with TRU and could be followed sonographically during treatment.

\section{CONCLUSIONS}

Transrectal ultrasonography (TRU) is an easy and reliable technique, well tolerated by the patient. Several parameters can be evaluated exactly by TRU : the structure and thickness of the rectal wall, the morphology and dimensions of the anal sphincter and the pelvic floor muscles. Linear ultrasonic scanning seems more performing than radial scanning in the evaluation of the morphology and especially the dynamic function of the anal sphincter.

In Crohn's disease, TRU reveals lesions ignored by routine proctosigmoidoscopy and provides a tridimensional view of their relationship with the surrounding tissues. The early detection of these lesions and of anomalies of the anal sphincter and the rectal wall enhances $a$ rapid and adequate treatment.

TRU appears as a very promising technique in the study of non neoplastic anorectal diseases. 